\title{
The Lower Miocene Nukhul Formation (Gulf of Suez, Egypt): microfacies and reservoir characteristics
}

\author{
Mostafa Temraz ${ }^{1} \cdot$ Henning Dypvik ${ }^{2}$
}

Received: 18 May 2017/Accepted: 22 August 2017/Published online: 11 September 2017

(c) The Author(s) 2017. This article is an open access publication

\begin{abstract}
The Lower Miocene Nukhul Formation was deposited during early stages of Gulf of Suez rifting. Outcrop of this formation at Gebel el Zeit, Egypt is up to $100 \mathrm{~m}(328 \mathrm{ft})$ in thickness and consists of lower sandstone-dominated and upper carbonate-dominated units. Samples were collected from the Nukhul Formation outcrop in order to describe the lithofacies, mineralogy, and petrographic characteristics to better understand the hydrocarbon reservoir potential of the unit. The investigations showed that the lower part of Nukhul Formation at North Gebel el Zeit consists of poorly sorted, dolomitic sandstone and sandy dolomite which were deposited in a shallow-marine setting. The presence of polycrystalline and crushed quartz grains in Nukhul strata indicates that these strata were sourced by recycled sediments associated with local uplift tied to rifting. The upper Nukhul consists of dolomitized carbonates with preservation of original textures; primary limestone depositional textures include intraclast packstone, rudstone, and coral-algal boundstone, wackestone, and grainstone with minor floatstone. Carbonate rock strata were deposited in shallow marine, peritidal to subtidal environments that developed on faultblock highs. The presence of zoned saddle dolomite suggests some component of fault-controlled fluid flow. Reservoir characteristics of the Lower Miocene Nukhul Formation at the Gebel el Zeit indicates favorable
\end{abstract}

Mostafa Temraz

gouda250@yahoo.com

Henning Dypvik

henning.dypvik@geo.uio.no

Egyptian Petroleum Research Institute (EPRI), Cairo, Egypt

2 Department of Geosciences, University of Oslo, Oslo, Norway properties for reservoir development in both the lower siliciclastic-dominated dolomite and the upper dolomitized carbonate portions of the formation.

Keywords Gebel el Zeit · Gulf of Suez · Lower Miocene · Nukhul Formation

\section{Introduction}

The major heavy oil accumulations in the Issaran field, Gulf of Suez, are trapped in Miocene fractured carbonate and siliciclastic reservoirs with average API between 10 and 12 (Joshi et al. 2010). The main early Miocene producer of this heavy oil is the highly fractured Nukhul Formation.

Numerous sedimentological and structural studies of rift evolution have been performed on the Gulf of Suez due to the presence of well-exposed, and relatively well-dated, syn-rift marine strata and the large amounts of exploration data available from region (Winn et al. 2001). The PermoTriassic to Holocene outcrops along the Gulf of Suez generally span continental to shallow marine environments.

The Oligocene-Miocene intracontinental Suez Rift formed a fault-bounded marine trough (Lorna et al. 2013). The early and middle Miocene syn-rift sedimentary sequences are dominated by terrigenous clastics from unroofing of the uplifted rift flanks or shoulders. These successions are among the most prolific petroleum reservoirs in the Suez province. A thorough understanding of their depositional history and controlling factors such as rift shoulders relief, the timing of unroofing, local paleogeography, and sedimentary deposystems is required for establishing an accurate development of known reservoirs and prediction in ongoing exploration. 
The Lower Miocene shallow marine Nukhul Formation is exposed at the Gebel el Zeit outcrop, Gulf of Suez Basin (Fig. 1). It is the oldest and most extensive syn-rift deposit in the Gulf of Suez (Fig. 2), and the Nukhul Formation is high-quality petroleum reservoir in more than 15 fields (Saoudi and Khalil 1986). The unit is generally interpreted to represent fluvial, alluvial fan, lagoonal, lacustrine, and shallow-marine environments in various structurally subdued basins. Some workers have also postulated more distal, possibly deep marine conditions for portions of the Nukhul Formation (McClay et al. 1998). Regionally it includes a mix of sandstones, conglomerates, limestones, shales, and evaporites.

At Gebel el Zeit, the Nukhul Formation consists of a lower siliciclastic interval and an upper carbonate interval representing shallow-marine conditions (Allam 1988; Evans 1990). However, the stratigraphic characteristics of the Nukhul Formation at Gebel el Zeit vary considerably
Fig. 1 Geologic map of the Gulf of Suez showing basement, pre-Miocene, Miocene outcrops, and detailed geologic map of North Gebel El Zeit

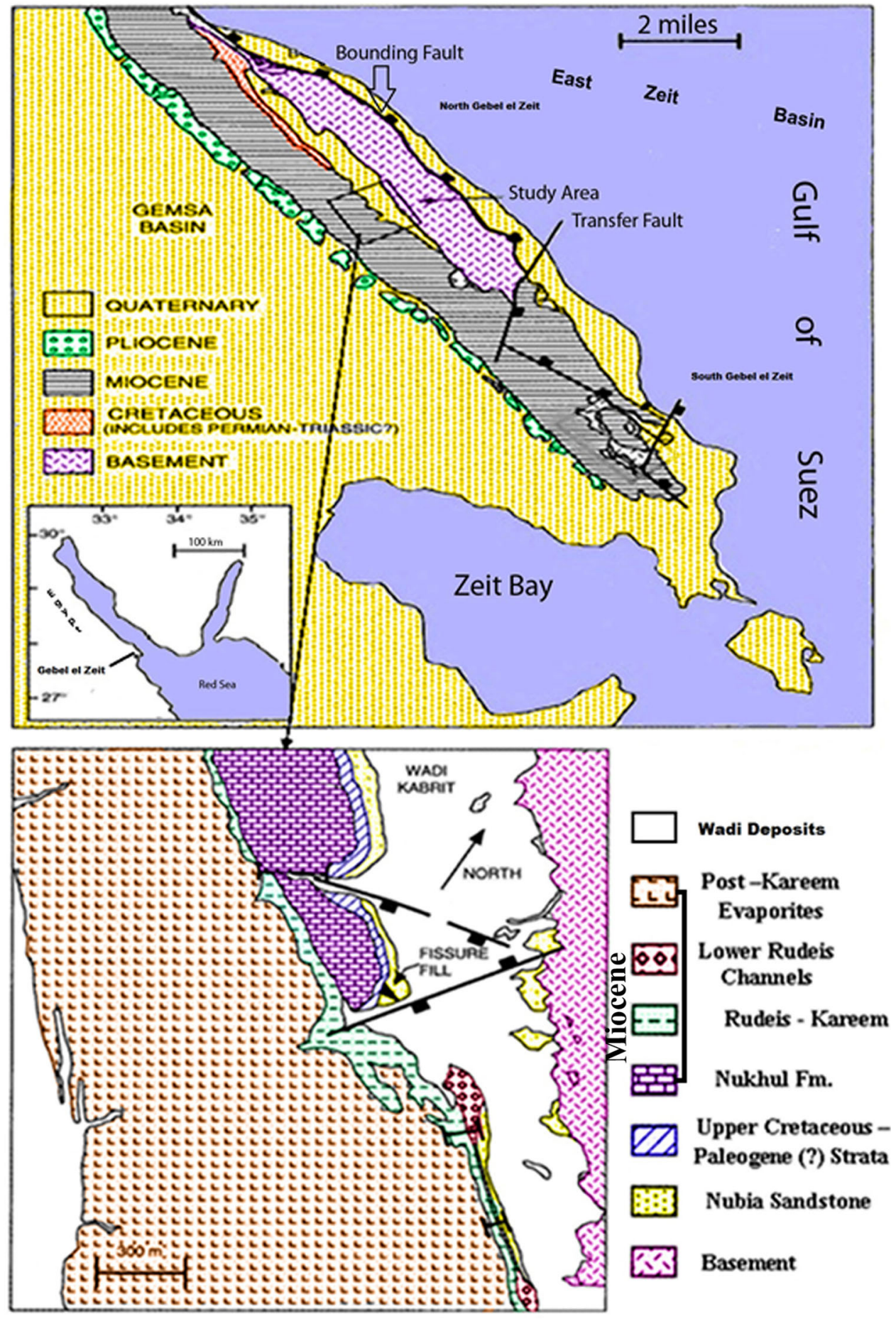


Fig. 2 Stratigraphic column of Gulf of Suez, with calcareous nanoplankton zonation and absolute ages with formational nomenclature of Hosny et al. (1987) (modefied from Evans 1988)

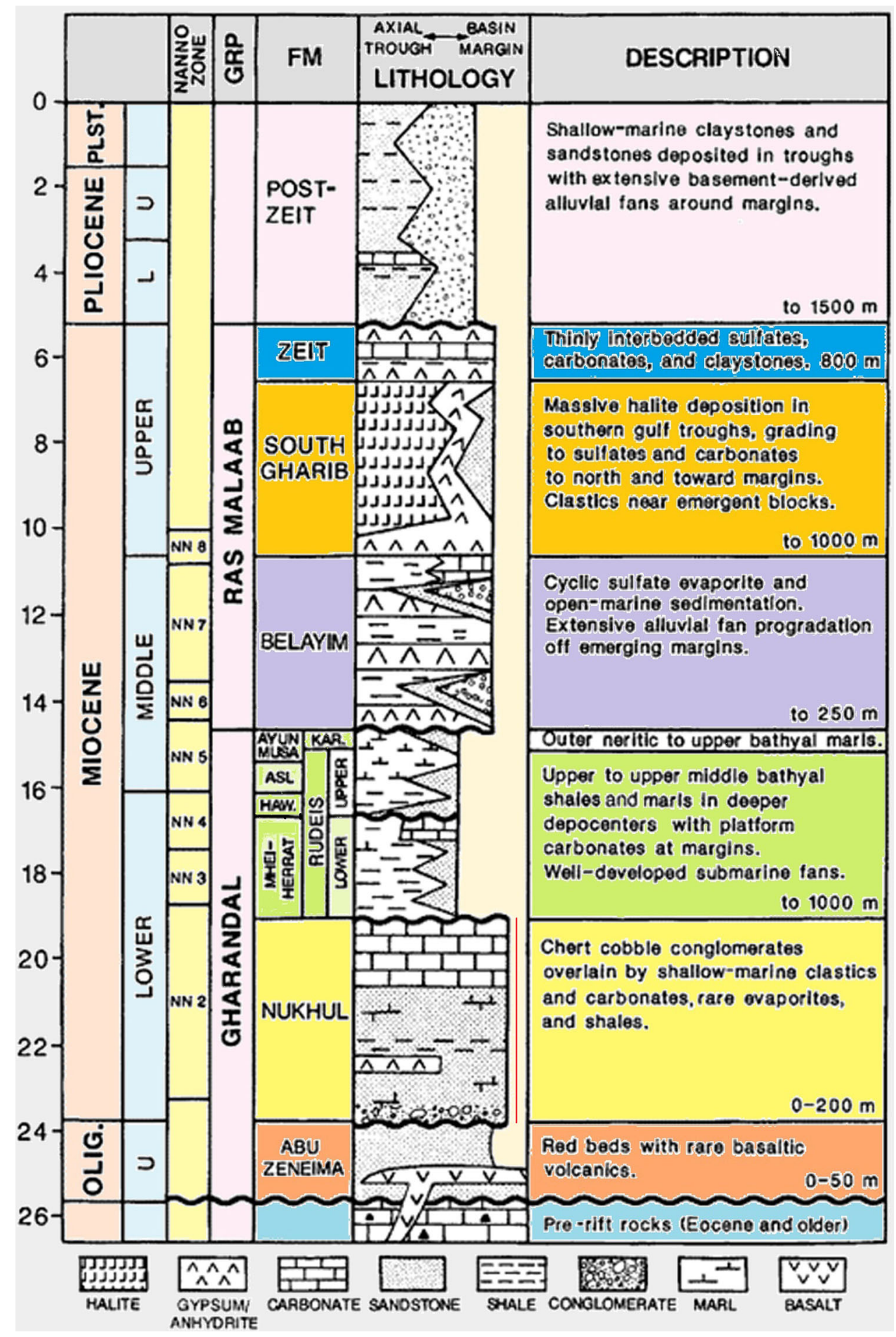

along strike. The thickness of Nukhul Formation is up to

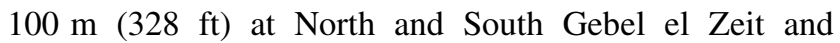
consists mainly of a lower sandstone and conglomerate unit and a dolomitized carbonate unit upper (Figs. 1, 2). Locally, the lower clastic interval may be absent. Nukhul strata are absent at Gebel el Zeit, where Rudeis-Kareem marl and shale can be found directly on pre-Nukhul units. Nukhul clastic and carbonate units are assumed to be approximately time equivalent in south and north Gebel el Zeit, although biostratigraphic information confirming synchroneity is lacking (Evans 1990). The Nukhul Formation is up to several hundred meters thick to the west and east of the study area in the Gemsa-Zeit Bay Basin and East Zeit Basin (Fig. 1) although maximum thicknesses are unknown due to sparse data from the basin centers (Bosworth et al. 1998). 
Fig. 3 East-west cross-section across the southern Gulf of Suez, showing the relationships between source rocks in the East Zeit Basin and migration pathways. Modified after Richardson and Arthur (1988)

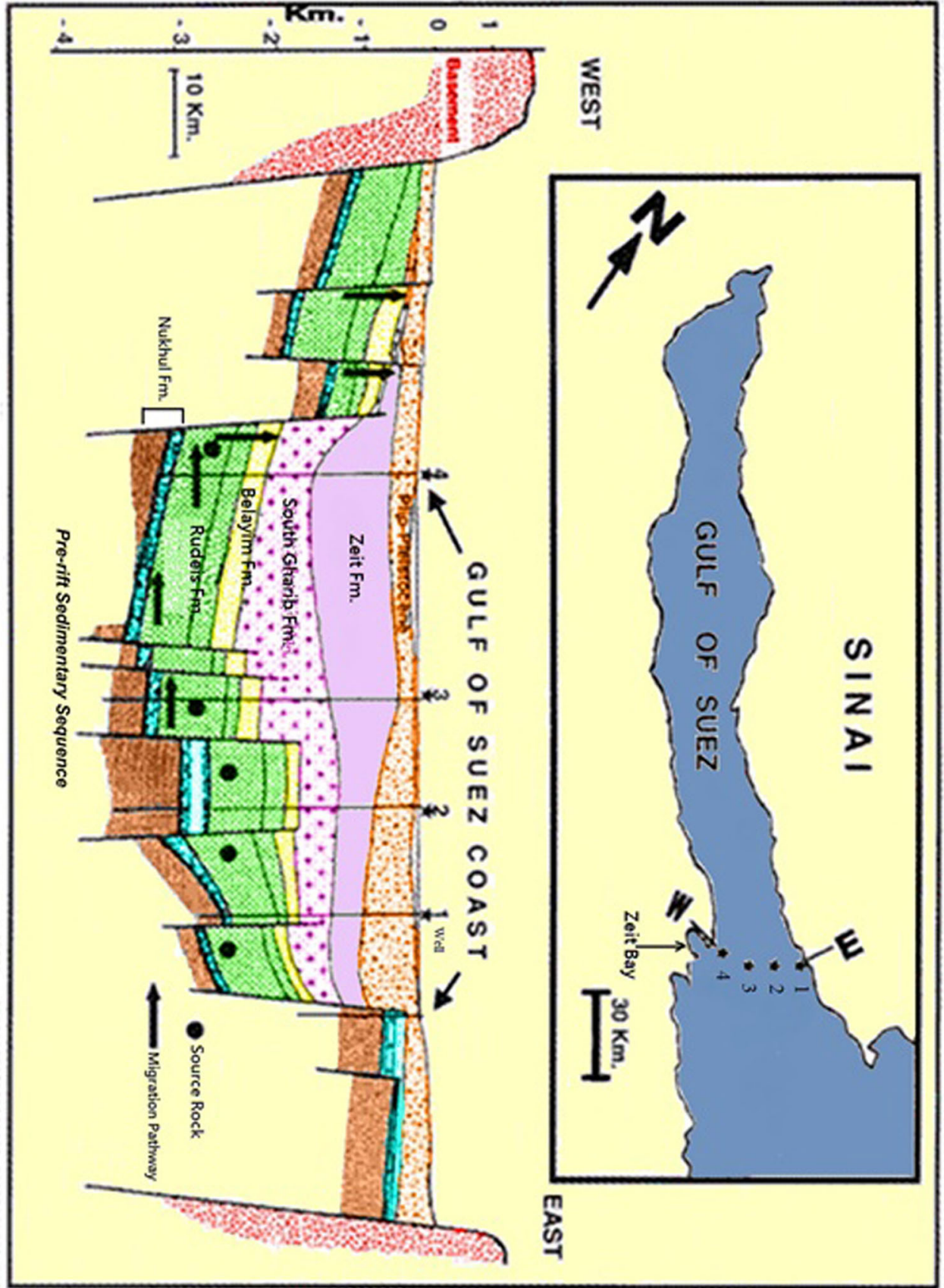

\section{Tectonic evolution of the suez gulf rift}

The Suez Gulf is a rifted basin where tectonic activity has strongly influenced the sedimentological and stratigraphic expression of rift-related strata. The fault extension-induced evolution exerts a primary control on sedimentation, controlling both fluid flow and creating sites of deposition (Gawthorpe and Leeder 2000; Mack et al. 2009; Lorna et al. 2013). Gulf of Suez rifting started in the late early Miocene (e.g., Evans 1990; Schutz 1994). Early syn-rift igneous rocks from the Gulf of Suez have been radiometrically dated to 24-21 Ma (early Miocene; Sellwood and Netherwood 1984), while the earliest Miocene and Oligocene rift-related faulting have been discussed by Patton et al. (1994). Apatite fission track ages of granitic basement indicate major uplift of the Red Sea Hills to the west of the Gulf of Suez (Fig. 1), associated with early rifting at 21-23 Ma (early Miocene) (Omar et al. 1989). Extensional movements along the northwestern Red Sea coast and early Miocene tilting of Gebel el Zeit fault blocks resulted in high relief and coarse grained alluvial deposits (Bosworth et al. 1998). Sedimentation focused in high 
Fig. 4 Lithostratigraphy of the studied Nukhul Formation at Gebel El Zeit

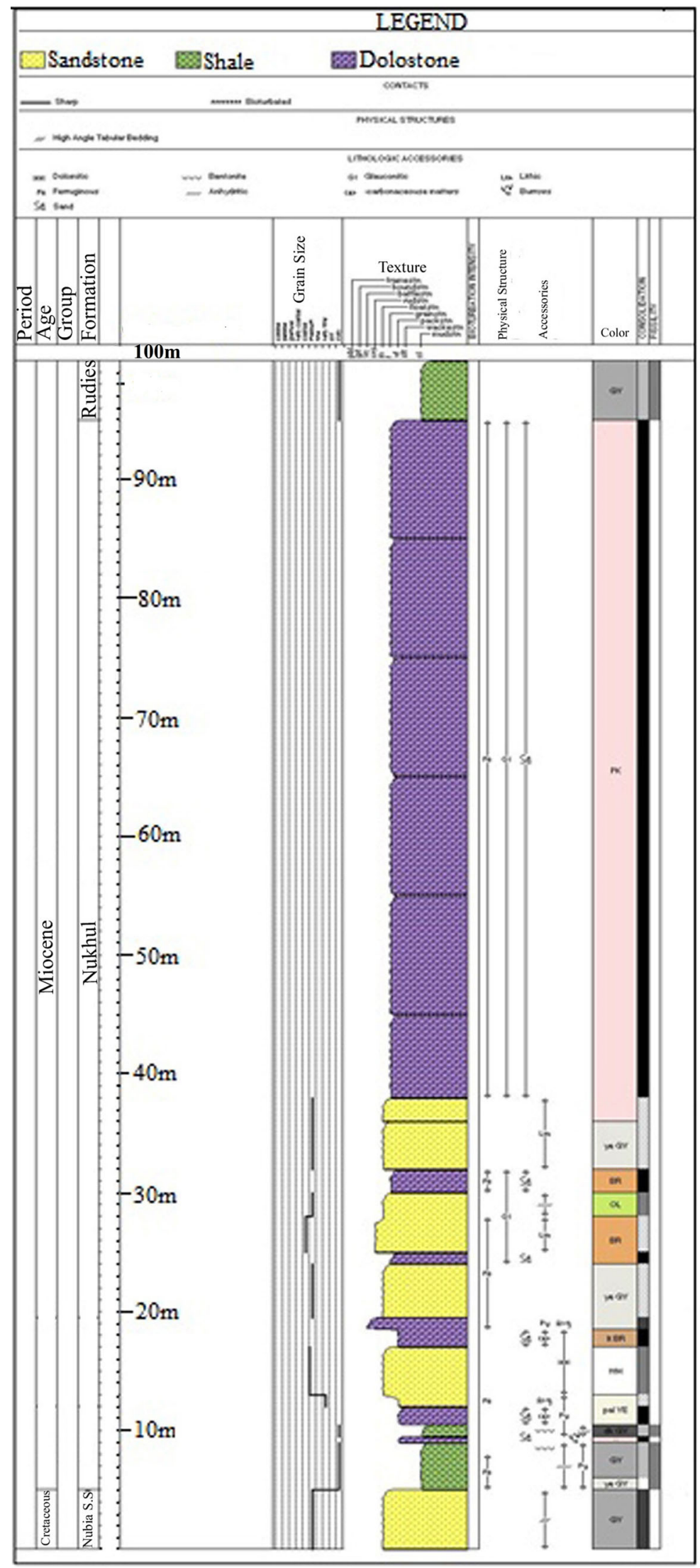




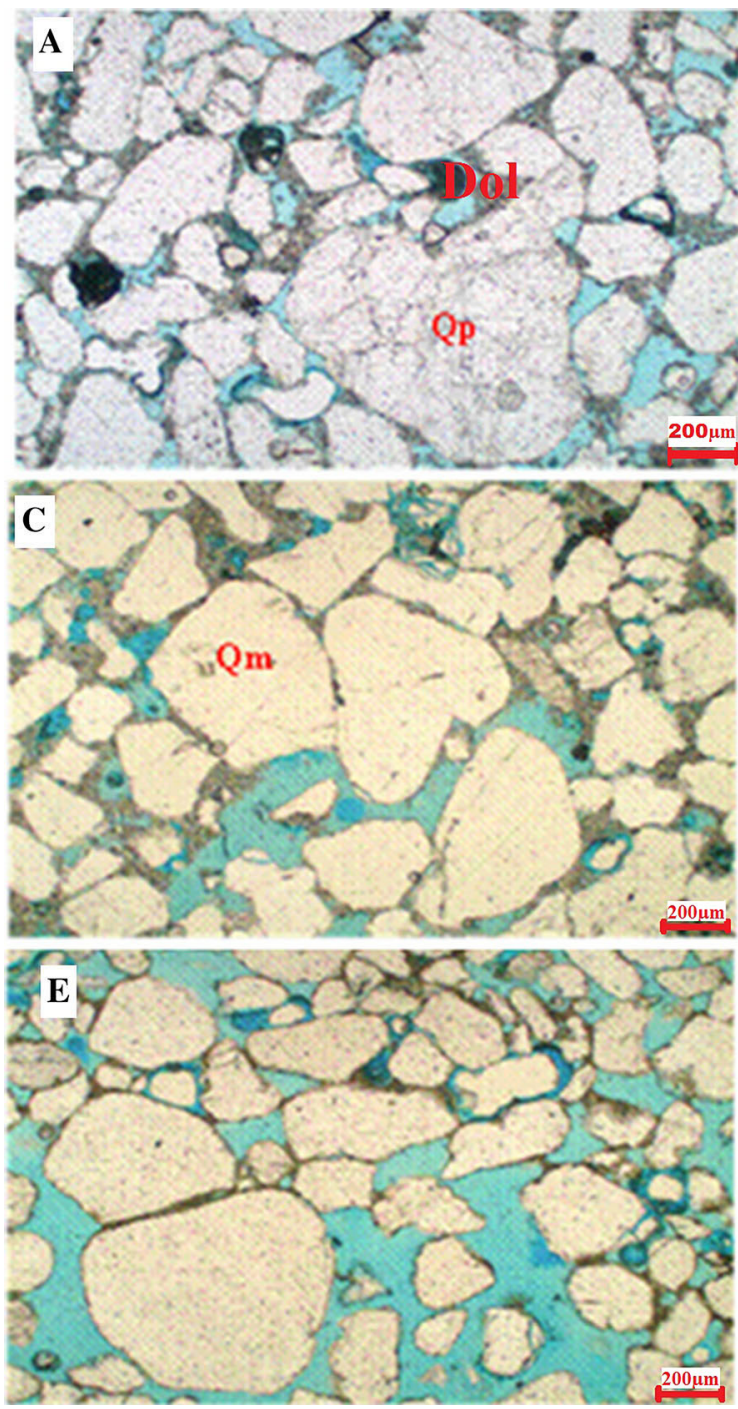

Fig. 5 a-e photomicrographs show siliciclastic-disseminated dolomite; a, b quartz arenite with sutured polycrystalline grains (PQ), highly porous, and slightly cemented with dolomite c, showing concave-convex and straight quartz grain contacts, $\mathbf{d}$ showing arenite

accommodation areas proximal to the active faults. Varying fault activity along bounding faults strongly influenced changes in depositional conditions (Bosworth et al. 1998).

Continued extension associated with widespread regional subsidence and associated transgression occurred in the late-lower to early-middle Miocene, and deep-water successions of Rudeis and Kareem formations were deposited (Fig. 2) (Omar et al. 1989).

Renewed rifting and subsidence took place in the southern Gulf of Suez in the late Miocene-Pliocene, resulting in deposition of the Belayim, South Gharib, and Zeit formations (Figs. 1, 2). Late Pleistocene-Holocene deformation at Gebel el Zeit is demonstrated by faulting within the Pleistocene successions, where outcrops of
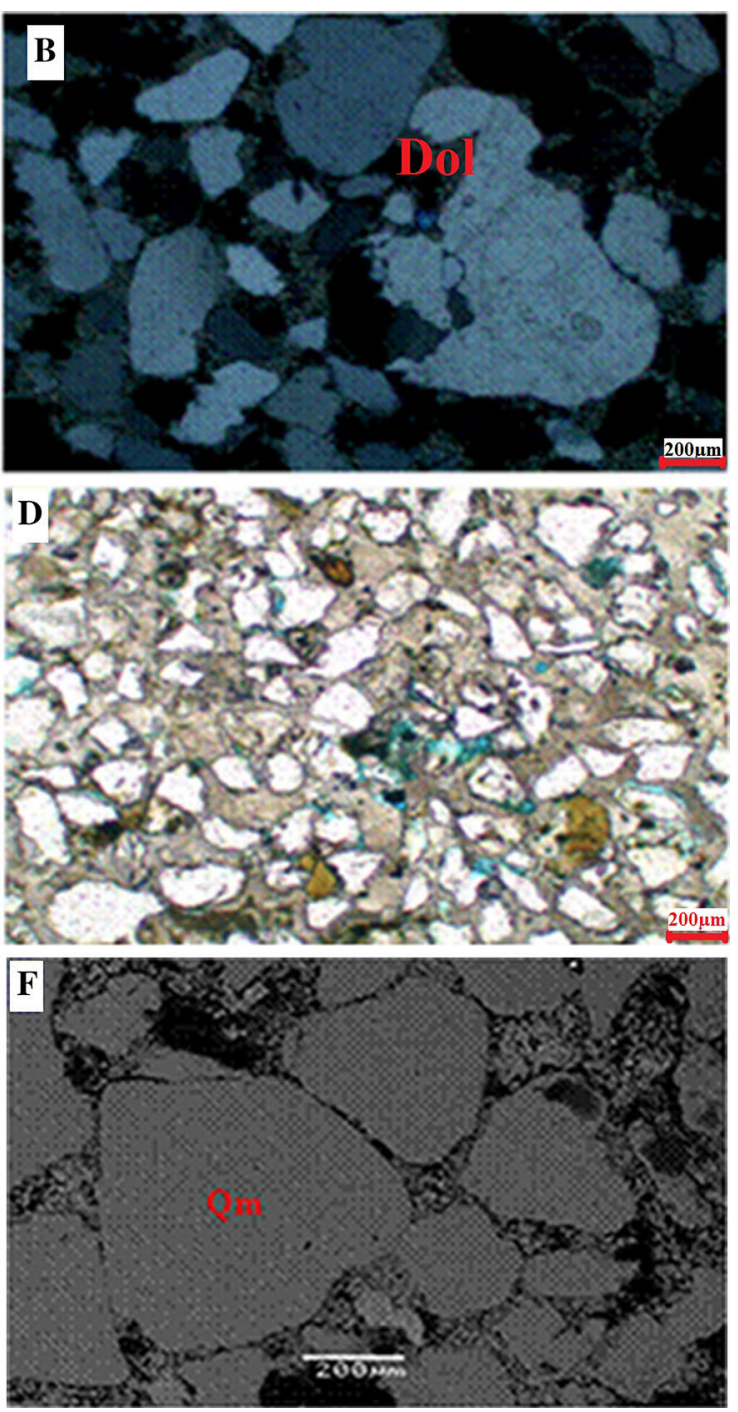

cemented by halite, e showing concave-convex and straight quartz grain contacts, and $\mathbf{f}$ showing SEM photomicrograph BSEI with quartz grains partially replaced by dolomite crystals. Bar scale is 200 um in all micrographs

Pleistocene reefs and ooid sand are found up to $150 \mathrm{~m}$ above the present sea level (Bosworth and Taviani 1996). The late Pleistocene-Holocene uplift appears associated with tilting since very young Pleistocene reefal deposits are present on the east side of Gebel el Zeit 10-18 m (32.8-59.04 ft) above sea level but are not raised at Zeit Bay to the southwest (Evans 1990). Modern earthquakes in the area reflect active faulting (Jackson et al.1988).

The modern Gulf of Suez region displays dramatic topographic relief, with denuded basement reaching elevations of nearly $2000 \mathrm{~m}(6560 \mathrm{ft})$ on the flanks. The depocenters along the axial trough may contain more than $5000 \mathrm{~m}$ (16,400 ft) of Neogene Syn-rift sediments (Fig. 3). 

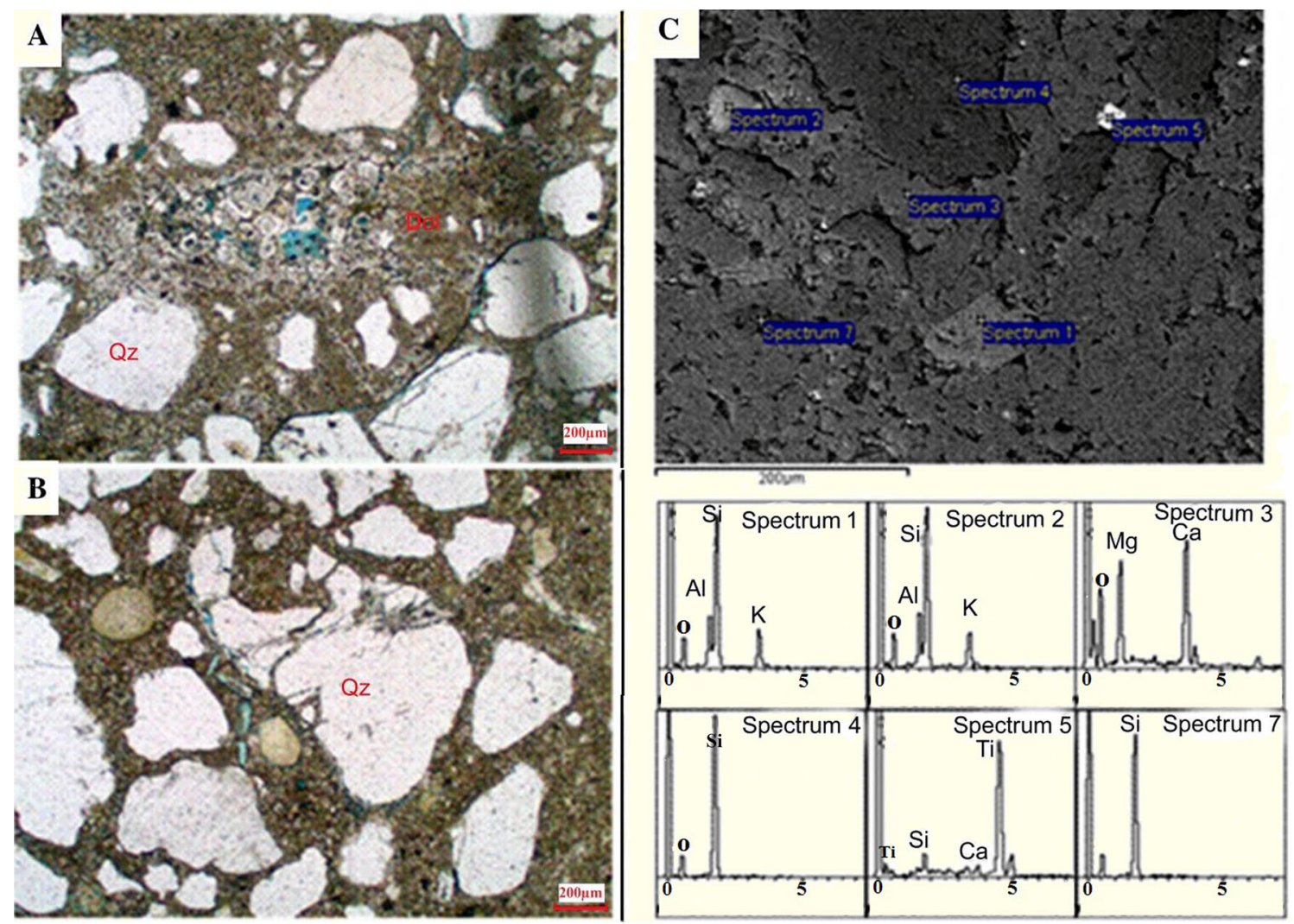

Fig. 6 a, b photomicrograph shows sandy dolomite: a sandstone with completely dedolomitized quartz grains. b Sandstone with partially dolomitized quartz grains. c SEM photomicrograph BSEI showing replacement of quartz grains by dolomite crystals as detected by EDX

\section{Methodology}

Samples from Nukhul Formation outcrops at Gebel El Zeit were collected to describe the lithofacies, mineralogy, and petrographic characteristics in order to evaluate its reservoir potential. Samples were impregnated with blue-stained epoxy, and then thin sectioned. Thin sections were stained with Alizarin Red in order to differentiate dolomite and calcite (Dickson 1965). Samples underwent petrographic analysis, optical microscopy, and analyses using SEM. Selected samples were crushed to rock powder for X-ray diffraction (XRD) analyses using a Philips PW3710 unit with rotating sample holder and secondary monochromatic electromagnetic wave.

\section{Results}

The studied Lower Miocene Nukhul Formation is characterized by a consistent upward succession from basal quartz sandstone to shale, then grading into sandy dolomite and later highstand marine carbonates (Fig. 4).

\section{Petrography and mineralogy}

The basal Nukhul Formation sandstone grades quickly upward into dolostones characterized by sparse (mostly molluscan) bioclasts and some burrowing. The dolostones develop upward into a variety of facies, often with variable amounts of admixed quartz sand.

The dolomites are recognized and classified according to crystal-size distribution (unimodal or polymodal) and crystal-boundary shape (planar or non-planar), according to Sibley and Gregg (1987). The classification is descriptive, but carries genetic implications, since size distribution and crystal boundary shape is controlled by nucleation and growth kinetics (Sibley and Gregg 1987; Amthor and Friedman 1991).

Based on its associations, the Nukhul-zoned dolomite occurs in three modes: siliciclastic-disseminated quartzrich dolomite, sandy dolomite, and pure zoned dolomite (Fig. 4).

\section{Siliciclastic disseminated dolomite}

This mode of dolomite consists of euhedral (idiotopic), finely crystalline material with crystals sizes less than $80 \mu \mathrm{m}$ scattered within the host sediments (Fig. 5). The

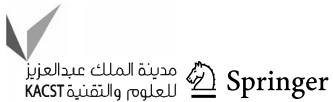



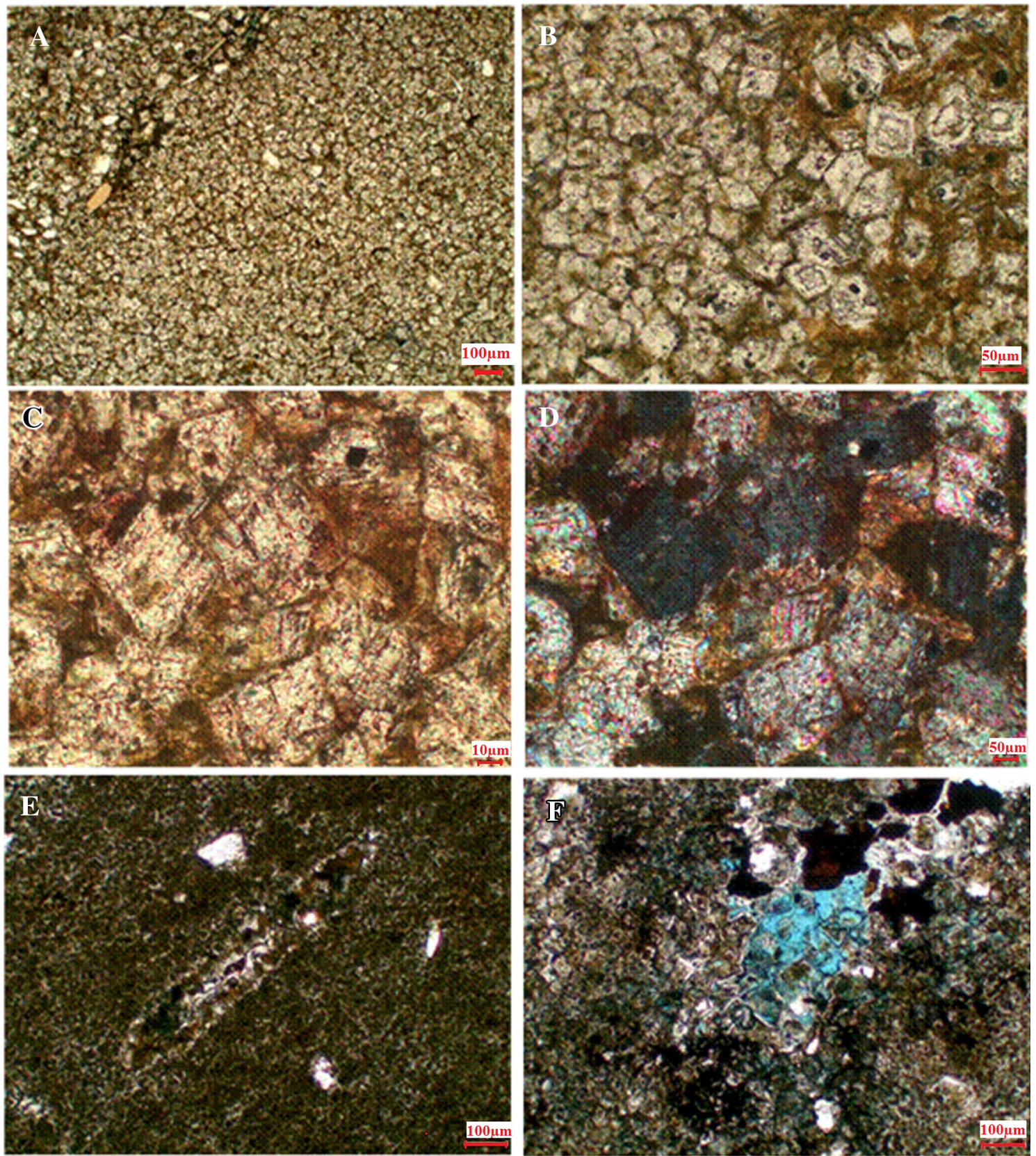

Fig. 7 a, b photomicrograph showing very fine crystalline planar-e mosaic-zoned dolomite. $\mathbf{c}, \mathbf{d}$ showing very fine crystalline planar-e to planar-s zoned dolomite PPl \&CN. e showing very fine crystalline

planar-e to planar-s zoned dolomite with "ghost" of early replaced foram texture. f showing very fine crystalline planar-e of recrystallized zoned dolomite with vugs and intracrystalline porosity

host sediments are chiefly composed of whitish to greenish grey, friable to slightly cemented quartz arenite (Fig. 5). The framework of this quartz arenite varies in size from very fine to pebbly grains, with subangular to sub-rounded, and moderately to well-sorted grains. Quartz grains are predominantly monocrystalline $(\mathrm{Qm})$ with straight extinctions, tangential and long, and concave-convex grain contacts. Some polycrystalline grains $(Q p)$ with sutured boundaries were observed locally

(Fig. 5a, b). The cementing materials in this microfacies commonly include disseminated dolomite, giving the rock a highly porous character (Fig. 5a, c, f). Halite cements stained with green (glauconite?) are also detected (Fig. 5d).

Concave-convex contacts between quartz grains as well as clear undulatory extinction (Fig. 5a, c) indicate stress on the quartz grains. 

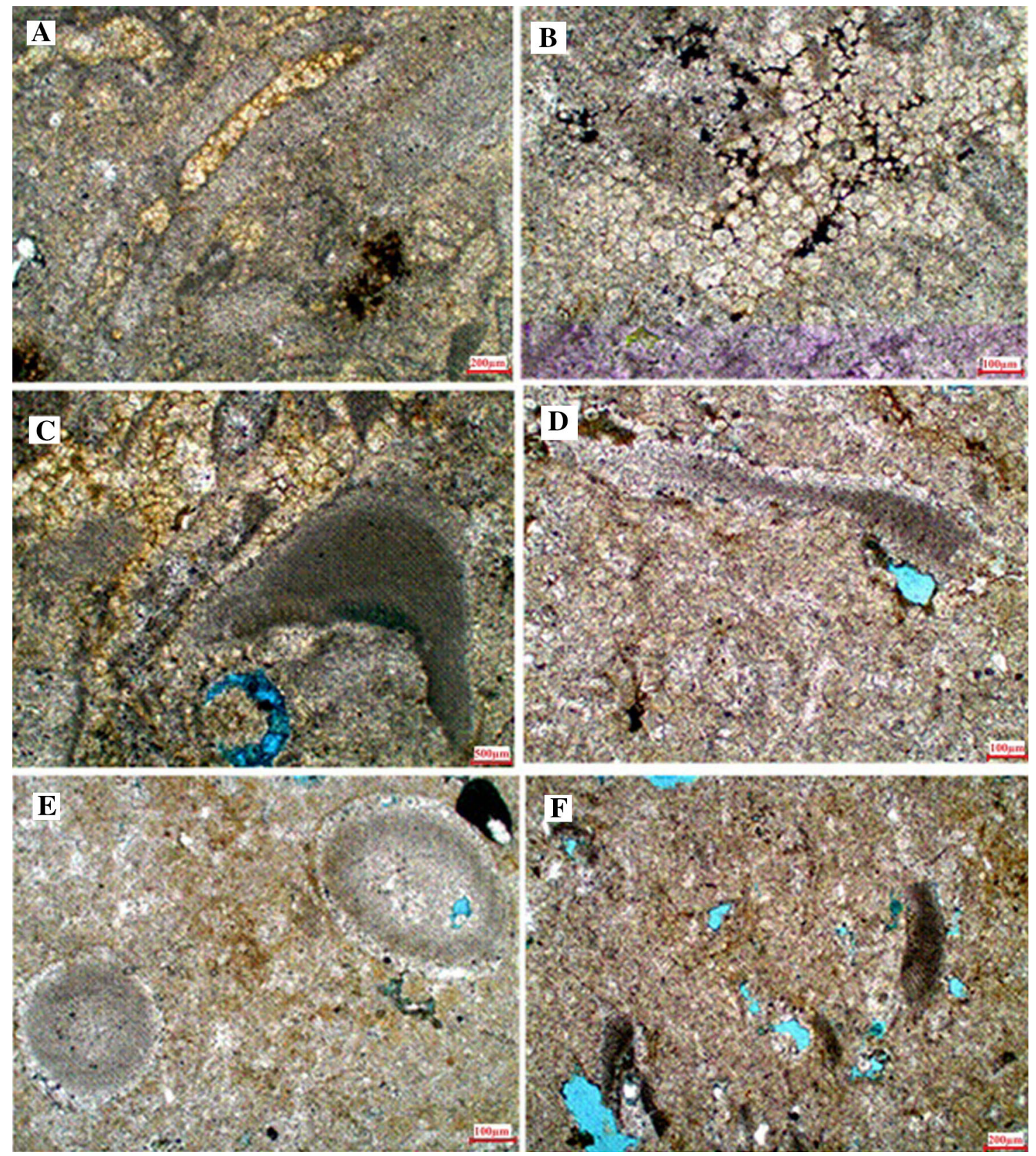

Fig. 8 a showing very fine crystalline planar-e to planar-s zoned dolomite with "ghost" of early replaced shell fragments texture. b showing very fine crystalline planar-e zoned dolomite with ferruginous cement. c, d showing very fine crystalline planar-e to planar-s zoned dolomite with red algae and ghosts of ooids, in $\mathbf{c}$ Red

algae ghosts and vugs are seen, in c, e showing very fine crystalline planar-e to planar-s zoned dolomite with "ghost" of early replaced ooids texture. $\mathbf{f}$ showing very fine crystalline planar-e of recrystallized zoned dolomite with vugs and intracrystalline porosity

\section{Sandy dolomite}

This lithology occurs as very fine planer-e, unimodal microcrystalline dolomite (less than $80 \mu \mathrm{m}$ in size) replaced host sediments (Fig. 6a-c) which are scattered throughout the host rock matrix. The quartz grains are partial to completely replaced by dolomite (Figs. 6, 7). The

replacive dolomite fabrics are associated with intracrystalline and "vuggy" porosity (Fig. 6). This porous dolomite generally is limited to the dolomitized sandstone lithofacies that represents the main constituent of the lower part of the studied Nukhul Formation.

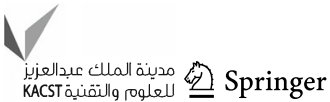


Fig. 9 showing XRD analysis results of the studied Nukhul Formation, the lower unit composed mainly of siliclastic disseminated dolomite, grades into sandy dolomite to completely dolomite in the upper part

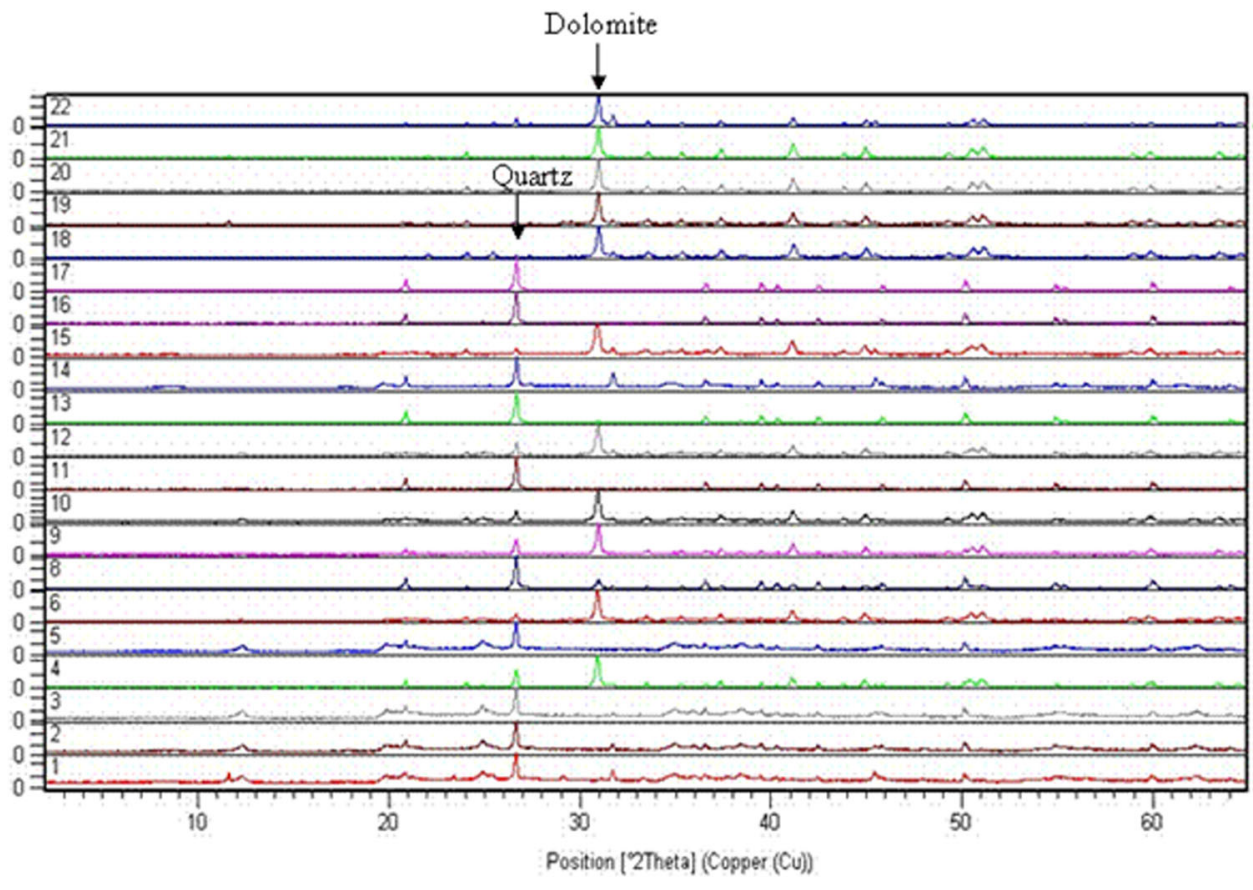

\section{Pure dolomite}

This facies occurs as very fine planer-e, unimodal microcrystalline dolomite (less than $80 \mu \mathrm{m}$ in size) cemented by ferruginous materials (Fig. 8). These typical euhedral-dolomite crystals resemble those described by Friedman and Sanders (1978) and Sibley (1982). This pure dolomite forms the main constituent of the upper unit of the studied Nukhul Formation (Fig. 4). The microcrystalline dolomites usually have well-developed microporosity, visible only in thin sections impregnated with fluorescent epoxy and viewed using ultraviolet light microscopy (Fig. 7f).

The pure dolomite forms dense mosaics of euhedral to subhedral planar-e (euhedral) crystals that have clear cores and rim textures (Fig. 7a-d) and non-mimic replacement of host allochems (ooids, peloids, intraclast, and fossil-fragments). These allochems can be recognized by their ghost textures (Figs. 7, 8).

These dolostones also are composed of fine to medium crystalline planar dolomite with intercrystalline pores, vugs, and some microporosity. Bioclasts are represented by algae and skeletal molds. The intense dolomite recrystallization has rendered most grains and many original fabrics unrecognizable petrographically (Fig. 8a-f). The host sediment often was a porous oolite with early calcite spar cement, which was subsequently completely replaced by dolomite (Fig. 8a, f).

XRD and petrographic analyses of Nukhul Formation confirm that the formation grades up from disseminated dolomite in lower, clastic-dominated section to sandy dolomite in middle section, and pure dolomite at the upper portion (Fig. 9).

\section{Discussion}

\section{Dolomitization and diagenesis}

The results of analysis on Nukhul Formation dolostones illustrate their complex diagenetic history which involves early diagenetic as well as burial diagenetic stages.

\section{Early diagenetic (penecontemporaneous) dolomitization}

Some observations suggest that Nukhul Formation dolomitization occurred shortly after the deposition of preexisting carbonate sediments, e.g., preservation of primary allochems (cf. fossils and ooids; Figs. 7, 8). Very fine euhedral-subhedral dolomite (locally anhedral) crystals show a clear internal texture with few fluid inclusions; these crystals also display unit extinction under crossed polarized light.

Petrographic evidence suggests that dolomite precipitated prior to or during early phases of compaction ( $\mathrm{Ye}$ 1992; Gu 2000; Qian and You 2006).

\section{Late diagenetic (Epigenic) dolomitization}

It is suggested that Mg-rich burial fluids ascended via deepseated joints, fractures, and faults caused by early Miocene 
Fig. 10 SEM photomicrograph shows very coarse euhedral quartz grains scattered in a very fine to fine crystalline planar-s (subhedral) mosaic sandy dolomite
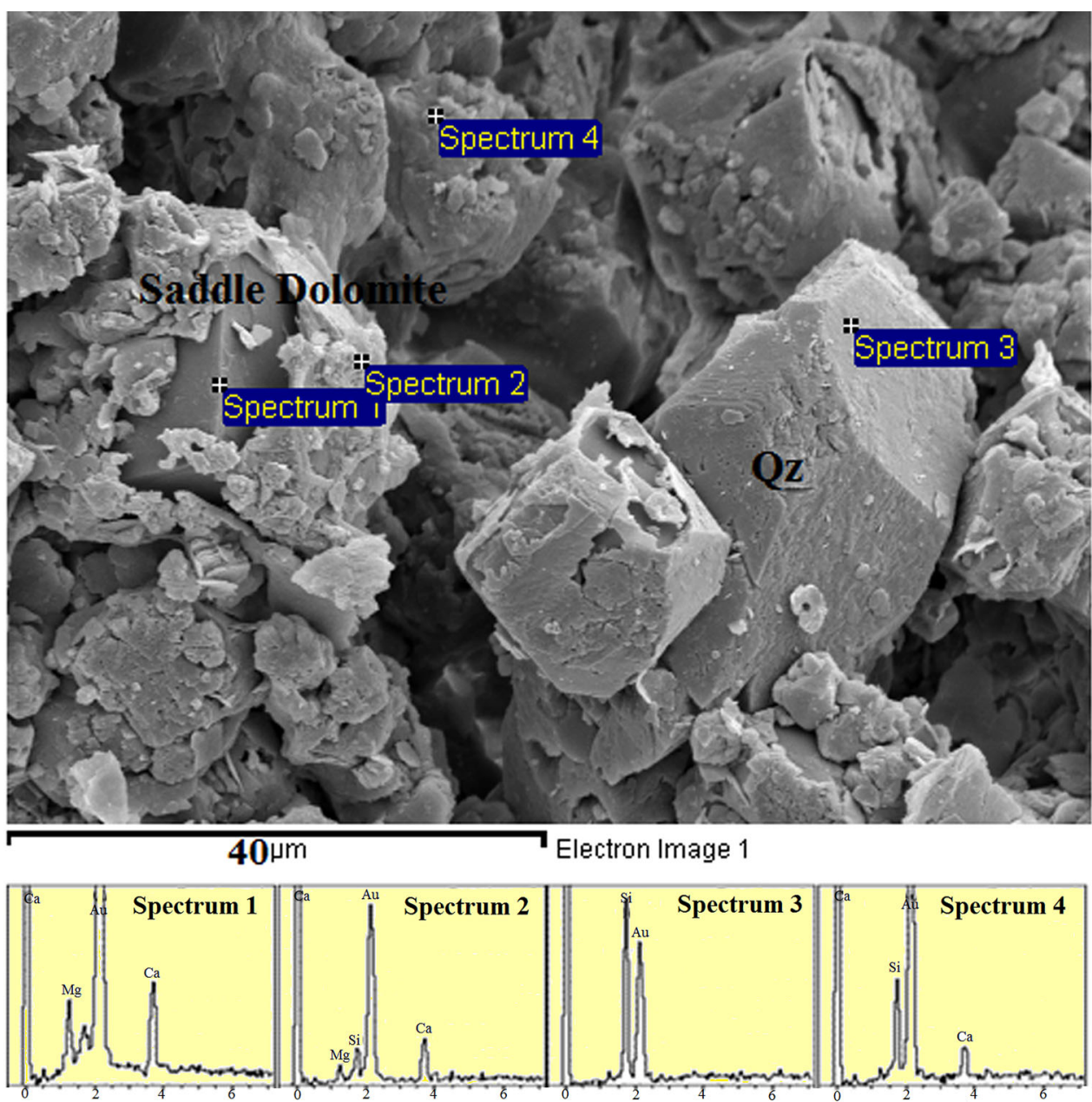

tectonics; these waters spread laterally along porous zones and bedding planes. The upward migration of the magnesium water was arrested by impervious shales.

These fluids are interpreted to account for the high degree of dolomitization in the lower parts of the Nukhul Formation (siliciclastic-disseminated dolomite; Fig. 10). In these dolomitized zones, the primary allochems and textural fabric have completely recrystallized.

In the lower siliciclastic portion of Nukhul Formation pores are partially filled with saddle dolomite crystals (Fig. 11). These dolomites are preferentially developed in fractured zones close to faults (Yang et al. 2007). This suggests that the formation of the saddle dolomites may be related to fault-controlled fluid flow. The saddle dolomites consist of clear non-planar euhedral dolomite crystals with an average size exceeding $1 \mathrm{~mm}$ and are characterized by curved crystal faces (Figs. 10 and 11). The backscattered electron (BSE) image of the saddle dolomites reveals their complex textures. As shown in Fig. 11, the saddle dolomites have core and cortex portions. The cortex is divided into multi cortex from inner to outer cortex (Fig. 11). The inner cortex is composed of dark-zoned non- and light ferroan dolomite, and each band varies in width. Outer cortex is characterized by dark non-ferroan dolomite with lightly thin-zoned ferroan dolomite. The width of the ferroan dolomite zone varies at different positions, and most of the zoned strips are linear. The complex petrography of the saddle dolomites suggests their complex origin.

\section{Reservoir characteristics}

Carbonate reservoirs are very important targets in oil and gas exploration. Globally carbonate reservoir rocks constitute $20 \%$ of the sedimentary rocks while they hold more than $50 \%$ of the world's proven hydrocarbon reserves and account for $40 \%$ of the world's total hydrocarbon production (Saberi 2010). Dolomitization, a diagenetic process is responsible for the transformation of limestone into dolomite. Diagenesis of limestone into dolomite involves the substitution of some $\mathrm{Ca}^{2+}$ ions in limestone $\left(\mathrm{CaCO}_{3}\right)$ by $\mathrm{Mg}$ ions to form dolomite $\mathrm{CaMg}\left(\mathrm{CO}_{3}\right)_{2}$. This process increases the crystal size, pore size and thus enhances the permeability. Porosity and permeability are also increased due to the solution of allochems. As dolomites are less 

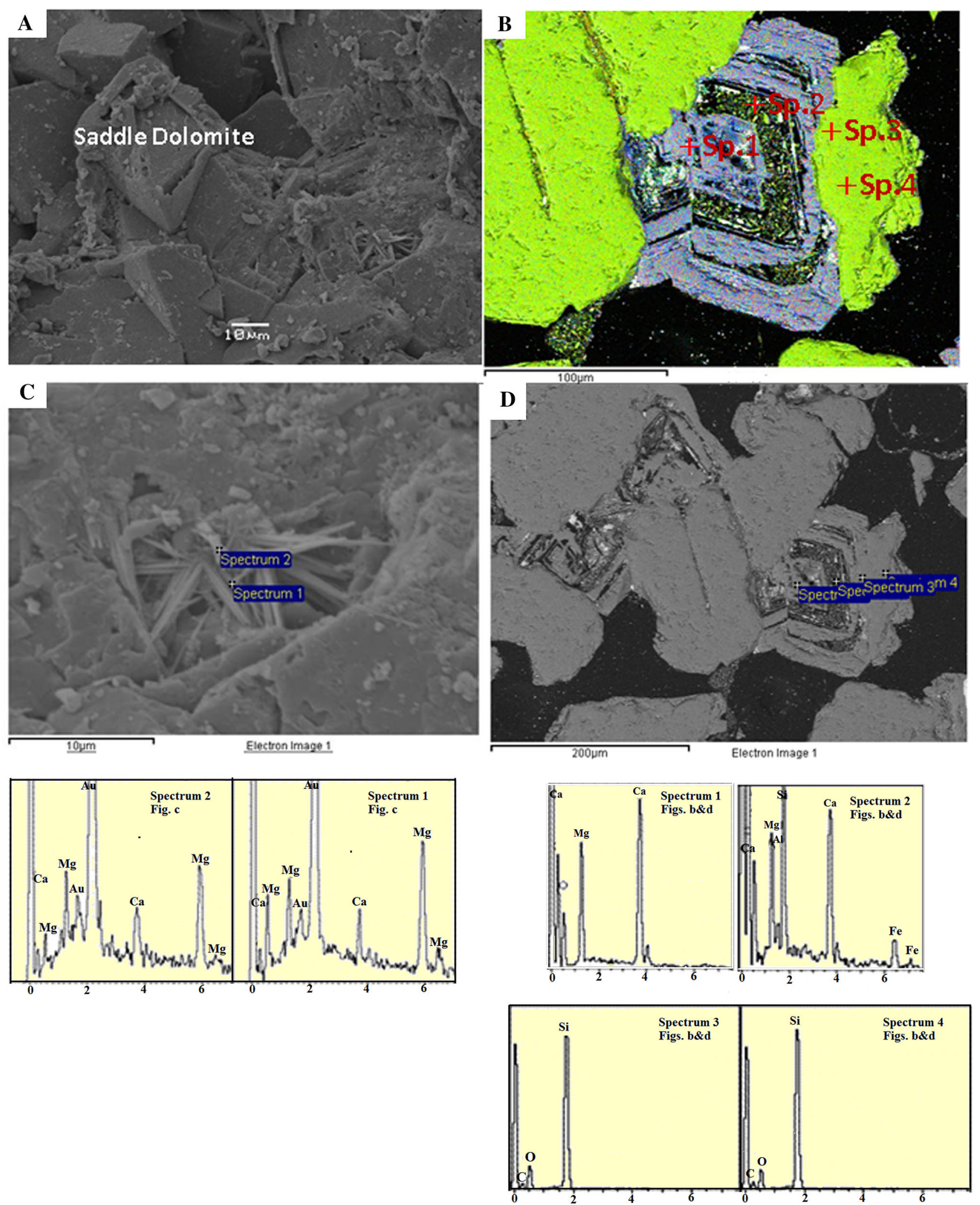

Fig. 11 SEM-BSE photomicrograph shows saddle dolomite crystals with inner core and multi cortex 
ductile relative to limestones and sandstones, their porosity and permeability are enhanced by fracturing too. Additionally, as they are less reactive than calcites, dolomites are less likely to lose porosity with depth due to dissolution or re-precipitation (Grammer and Harrison 2003). For the reasons described above, dolomites often make the best reservoirs in carbonates. The studied dolomite succession of Nukhul Formation is among the most prolific petroleum reservoirs in the Suez province. A thorough understanding of their depositional and diagenetic history (including sedimentary deposystems, local paleogeography, rift shoulder relief, and timing of unroofing) is required for establishing an accurate development of known reservoirs and prediction in ongoing exploration. This study documents at least two diagenetic stages of dolomitization with very different expression and areal extent.

\section{Conclusion}

Gebel el Zeit at the southern end of the Gulf of Suez represents an uplifted part of the central Gulf of Suez rift. The oldest syn-rift strata at the Gebel el Zeit are the Lower Miocene Nukhul Formation, which preserves the early sedimentary record of rifting. The high angular discordance between prerift and syn-rift strata at South Gebel el Zeit and dispersed facies relationships indicate that South Gebel el Zeit rotated more than North Gebel el Zeit during early Nukhul deposition.

The lower clastic-dominated interval of the Nukhul Formation in North Gebel el Zeit is interpreted as shallowmarine sediment gravity flow deposit that partially filled submarine gullies that funneled debris from uplifted areas.

The upper carbonate-dominated unit of the upper Nukhul Formation is composed mainly of pure dolomite microfacies. This dolomite was formed by complete replacement of carbonates during both early burial and late burial via hydrothermal basinal fluids. Early formed dolomites display preserved primary textures, while zoned, saddle dolomite crystals indicate later, fault-controlled fluid flow.

Acknowledgements This study was performed during a research stay of Dr Temraz at Department of Geosciences, University of Oslo, Norway, which was highly appreciated. This work is jointly funded by the Research Council of Norway, (Project No. 195631।V11 Yggdrasil program) and by the Egyptian Petroleum Research Institute, Cairo, Egypt.

Open Access This article is distributed under the terms of the Creative Commons Attribution 4.0 International License (http:// creativecommons.org/licenses/by/4.0/), which permits unrestricted use, distribution, and reproduction in any medium, provided you give appropriate credit to the original author(s) and the source, provide a link to the Creative Commons license, and indicate if changes were made.

\section{References}

Allam A (1988) A lithostratigraphical and structural study on Gebel el-Zeit area, Gulf of Suez, Egypt. J Afr Earth Sci 7:933-944

Amthor JE, Friedman GM (1991) Dolomite rocks textures and secondary porosity development in ellenburger group carbonates (lower ordovician), west Texas and southeastern New Mexico. Sedimentology 38:343-362

Bosworth W, Taviani M (1996) Late Quaternary reorientation of stress field and extension direction in the southern Gulf of Suez, Egypt: evidence from uplifted coral terraces, mesoscopic fault arrays, and borehole breakouts. Tectonics 15:791-802

Bosworth WP, Crevello P, Winn RD Jr, Steinmetz J (1998) Structure, sedimentation, and basin dynamics during rifting of the Gulf of Suez and northwestern Red Sea. In: Purser BH, Bosence DJW (eds) Sedimentary and tectonic evolution of rift basins: the Red Sea-Gulf of Aden. Chapman and Hall, London, pp 77-96

Dickson JAD (1965) A modified staining technique for carbonates in thin section. Nature 205:587

Evans AL (1988) Neogene tectonic and stratigraphic events in the Gulf of Suez rift area, Egypt. Tectonophysics 153:235-247

Evans AL (1990) Miocene sandstone provenance relations in the Gulf of Suez: insights into syn-rift unroofing and uplift history. AAPG Bull 74:1386-1400

Friedman GM, Sander JE (1978) Principles of sedimentology. Wiley, New York, p 792

Gawthorpe RL, Leeder MR (2000) Tectono-sedimentary evolution of active extensional basins. Basin Res 12:195-218

Grammer GM, Harrison WB III (2003) An overview of hydrothermal dolomite (HTD) reservoirs with examples from the Michigan Basin: Presentation for the Michigan Geological Survey. http:// wsh060.westhills.wmich.edu/RPSEA/refs/HTDoverview/HDO. pdf. Accessed 19 Mar 2014

Gu JY (2000) Characteristics and origin analysis of dolomite in lower Ordovician of Tarim Basin. Xinjiang Petro Geol 21:120-122

Hosny W, Gaafar I, Sabour AA (1987) Miocene stratigraphic nomenclature in the Gulf of Suez region. In: Hantar G (ed.) Egyptian GPC eighth exploration seminar, preprint

Jackson JA, White NJ, Garfunkel Z, Anderson H (1988) Relations between normal-fault geometry, tilting and vertical motions in extensional terrains: an example from the southern Gulf of Suez. J Struct Geol 10:155-170

Joshi S, Thabet E, Abugreen Y, Samir M, Hassan W, Omara M (2010) Identifying reservoir pathways in a fractured dolomitic heavy oil reservoir. SPE 129098

Lorna JS, Frank R, Robert LG, Paul W, Ian S, Dave H (2013) Submarine slope processes in rift-margin basins, Miocene Suez Rift, Egypt. GSA Bull 125:109-127

Mack GH, Leeder MR, Perez-Arlucea M (2009) Late Neogene riftbasin evolution and its relation to normal fault history and climate change along the southwestern margin of the Gerania Range, central Greece. Geol Soc Am Bull 121:907-918

McClay KR, Nichols GJ, Khalil SM, Darwish M, Bosworth W (1998) Extensional tectonics and sedimentation, eastern Gulf of Suez, Egypt. In Purser BH, Bosence DJW (eds.) Sedimentary and tectonic evolution of rift basins: the Red Sea-Gulf of Aden. London, Chapman and Hall, pp 223-238

Omar GI, Steckler MS, Buck WR, Kohn BP (1989) Fission-track analysis of basement apatites at the western margin of the Gulf

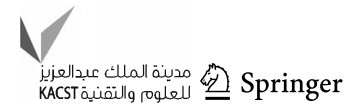


of Suez rift, Egypt: evidence for synchroneity of uplift and subsidence. Earth Planet Sci Lett 94:316-328

Patton TL, Moustafa AR, Nelson RA, Abdine SA (1994) Tectonic evolution and structural setting of the Suez rift. In Landon SM (ed.) Interior rift basins: AAPG Memoir 59, pp 9-55

Qian YX, You DH (2006) An analysis of Ordovician dolomitisation origin in northwestern Tazhong area. Xinjiang Petrol Geol 27:146-150

Richardson M, Arthur MA (1988) The Gulf of Suez-northern Red Sea neogene rift: a quantitive basin analysis. Mar Pet Geol 5(3):247-270

Saberi MR (2010) An integrated approach for seismic characterization of carbonates. Ph.D. dissertation, University of Bergen

Saoudi A, Khalil B (1986) Distribution and hydrocarbon potential of Nukhul sediments in the Gulf of Suez. In: Proceedings of the 7th exploration seminar, vol 1. Egyptian General Petroleum Corporation, Cairo, pp 75-96

Schutz KI (1994) Structure and stratigraphy of the Gulf of Suez, Egypt. In: Landon SM (ed) Interior rift basins, vol 59. American Association of Petroleum Geologists, Memoirs, Tulsa, pp 57-96
Sellwood BW, Netherwood RE (1984) Facies evolution in the Gulf of Suez area: sedimentation history as an indicator of rift initiation and development. Mod Geol 9:43-69

Sibley DF (1982) The origin of common dolomite fabrics, clues from the Pliocene. J Sediment Petrol 52:1087-1100

Sibley DF, Gregg JM (1987) Classification of dolomite rock texture. J Sediment Res 57:967-975

Winn D Jr, Robert D, Paul B Crevello, William B (2001) Lower Miocene Nukhul Formation, Gebel el Zeit, Egypt: model for structural control on early syn-rift strata and reservoirs, Gulf of Suez. AAPG Bull 85:1871-1890

Yang MH, Jin ZJ, Lu XX, Pan WQ, Hu JF (2007) Basement-involved transpressional structure and the formation of the Bachu Uplift, Tarim Basin, Northwestern China. Acta Geol Sin 81:158-165

Ye DS (1992) The origin of the Qiulitage Group dolomite (Cambrian to Ordovician) in northern Tarim Basin. Acta Sedimentol Sin 10:77-86 